University of Nebraska - Lincoln

DigitalCommons@University of Nebraska - Lincoln

\title{
$6-2013$
}

\section{Individual discourse, language ideology and Spanish transmission in El Paso, Texas}

Isabel Velázquez

University of Nebraska-Lincoln, mvelazquez2@unl.edu

Follow this and additional works at: https://digitalcommons.unl.edu/modlangspanish

Velázquez, Isabel, "Individual discourse, language ideology and Spanish transmission in El Paso, Texas" (2013). Spanish Language and Literature. 106.

https://digitalcommons.unl.edu/modlangspanish/106

This Article is brought to you for free and open access by the Modern Languages and Literatures, Department of at DigitalCommons@University of Nebraska - Lincoln. It has been accepted for inclusion in Spanish Language and Literature by an authorized administrator of DigitalCommons@University of Nebraska - Lincoln. 


\title{
Individual discourse, language ideology and Spanish transmission in El Paso, Texas
}

\author{
Isabel Velázquez \\ Department of Modern Languages and Literatures, University of Nebraska-Lincoln, 1127 Oldfather Hall, \\ Box 880315, Lincoln, NE, 68588-0315, USA; email mvelazquez2@unl.edu
}

\begin{abstract}
This paper reports the results of an analysis of the use of metaphors, metonyms, referential strategies, and expressions of deixis used by a group of middle-class bilinguals in the border city of El Paso, Texas, when speaking about use of Spanish and English in their city and in their home. A total of 234 metaphors referencing processes, institutions, and ethnic groups related to Spanish/English use were included. The goal of this study was to analyze how speakers conceptualized language use and language users in their community, and to examine if and how individual discourses map onto larger linguistic ideologies. The study of language ideologies and individual discourse as related to language maintenance and shift in El Paso illustrates the tensions between ideologies of language pride and language panic that are central to the Mexican American language experience. Examples of internalization of linguistic prejudice prevalent in public discourse about Latinos were found together with examples of the contestation of language panic discourse through the positioning of bilingualism as the key to economic mobility and local identity.
\end{abstract}

Keywords: Spanish, bilingualism, language transmission, metaphor, deixis, discourse analysis, language ideology, identity, Mexican Americans

This paper reports the results of an analysis of the metaphors, metonyms, referential strategies, and expressions of deixis employed by a group of middle-class bilinguals in the city of El Paso, Texas, when speaking about use of Spanish and English in their city and in their family. Founded in 1659, El Paso is the third oldest site of Spanish-English contact in the USA, and a city with a sustained history of bilingualism (Hidalgo, 1995; Teschner, 1995), and high ethnolinguistic vitality for Spanish. It is also a site of ethnic, linguistic, cultural, and transnational contact, with a long history of economic interdependence and intercultural tensions. The corpus for this analysis comes from seven hours of recorded interviews which are part of a larger study on parental attitudes and motivations towards Spanish use and maintenance in three Mexican American (MexAm) communities. The goal of this paper is to examine how these speakers conceptualized language use and language users, as an attempt to understand if and how individual discourse maps onto larger language ideologies. A detailed description of household language practices and patterns of Spanish maintenance and shift in these families can be found in Velázquez (2008).

The study of language ideologies and individual discourse as related to Spanish maintenance and shift in El Paso illustrates the tensions between language pride and language panic that are central to the MexAm language experience (Martínez, 2006). As will be exemplified below, El Paso bilinguals both internalize and contest national discourses that position Latinos as the racialized other, and that depict Spanish as a threat to national identity (Achugar, 2008; Olneck, 2006; Santa Ana, 2002; Velázquez, 2009). 
At a macro-level, Del Valle $(2000,2006)$, has described this tension as the ideological contrast between a linguistic culture of monoglossia, on one hand, which often characterizes official language policy efforts, and a linguistic culture of heteroglossia, which is more closely aligned with the experience of speakers in a multilingual community. In his analysis of the ideological underpinnings of language policies in Galicia, Del Valle (2000) argues that in this region of Spain, popular linguistic culture differs from the one that mediates the dominant views on language because the availability of several norms of linguistic behavior constitutes a source of ethnic identity (p. 127). This is also the case of El Paso, but, as will be argued here, a linguistic culture of heteroglossia at the community level, does not preclude the influence of monoglossic views on language at the individual speaker level.

Kroskrity (2000) points out that members of the same speech community may display varying degrees of awareness of local language ideologies (p. 18), and that these ideologies may be best conceptualized as multiple "because of the multiplicity of meaningful social divisions (...) within sociocultural groups that have the potential to produce divergent perspectives expressed as indices of group membership" (p. 12). Language ideologies will be understood here as "sets of beliefs about language articulated by users as a rationalization or justification of perceived language structure and use" (Silverstein, 1979, p. 193 in Kroskrity, 2000, p. 5).

The main argument to be made throughout this paper is that examination of metaphorical references, metonyms, referential strategies, and expressions of deixis related to language use and language users is one way to understand how individual discourse maps onto larger language ideologies. It will also be argued that speaker beliefs about the benefits and drawbacks of language maintenance and loss are couched within the larger landscape of community and national discourses about language use, and are fuelled by a wide range of subjective processes - e.g. perceptions, attitudes, motivations, social stereotypes. This is in line with current research that explores socio-psychological factors as a driving force behind language variation and change (Kristiansen, Garret, \& Coupland, 2005).

\section{Why metaphor?}

Metaphorical expressions are examined here in an attempt to understand the ways in which a group of bilingual speakers reproduces or contests dominant language ideologies about Latinos and Spanish language use and transmission. Achugar (2008) surveys the metaphors employed by several institutional actors in El Paso to refer to bilingualism and bilinguals, and documents the ways in which these contest national monolingual ideologies. The examples included in the present article contrast with Achugar's examples of academic and media discourses, in that they were produced by speakers who were not in the business of articulating public opinions about language use in their community. Examination of discourse produced by both types of actors can help us understand the impact of ideological processes on language use in multilingual communities.

Why study metaphors to access language ideologies? Because metaphors are not only linguistic tropes, but a cognitive resource through which we represent reality and make sense of the world (Hart, 2010; Lakoff \& Johnson, 2003). Metaphors play a strategic role in the construction of ideology in three distinct ways: They provide a cognitive framework for our worldviews (Santa Ana, 2002); they are intimately bound with affect (Hart, 2010), and they perform referential and predicational functions in the construction of in-groups and out-groups (Resigl \& Wodak, 2001, p. 58, in Hart, 2010, p. 56). Hart (2010) argues that metaphors achieve important cognitive, emotive, and perlocutionary effects by projecting particular qualities, quantities, and relations from the source domain onto the target domain (p. 128). A powerful exam- 
ple of this is Santa Ana's (2002) empirical study of representations on Latinos in newspaper items published in California during the 1990s. Santa Ana finds that in these accounts "Latinos were debased in terms of metaphors used in everyday speech. (...) By way of such metaphors, the current image of Latinos in the public's imagination took hold" (p. 7). This leads him to conclude that: "Metaphor in discourse is a window on the ways that Americans frame their domestic worldview, and on their underlying political and social values" (p. 8).

In a most basic sense, the term metaphor can be understood as any instance of non-literal language that involves some kind of comparison or identification. If interpreted literally, this comparison would be nonsensical or untrue (Knowles \& Moon, 2006). Knowles and Moon (2006) distinguish between creative (or novel) metaphors, in which "the reader/hearer needs to deconstruct or "unpack" in order to understand what it meant" (p. 5), and conventional metaphors that are institutionalized as a part of everyday language, and are not normally recognized by readers/hearers as a metaphor (p. 10). Metaphors will be understood here as "a cognitive operation performed in order to make sense of experience" and "a cognitive tool used to conceptualize subjective experiences and intangible social situations" (Hart, 2010, p. 127). In other words, metaphor is a way of thinking and orienting ourselves in the world, not just a way of speaking.

Elaborating on Lakoff and Johnson's work, Kövecses (2002) distinguishes between conceptual metaphors, in which one domain of experience is understood in terms of another through a set of systematic correspondences - or mappings, and metaphorical linguistic expressions, which are the linguistic expression of this cognitive operation (p. 12). According to their cognitive function, Kövecses (2002) classifies conceptual metaphors into three categories: Structural metaphors - which map the structure of the source domain to the structure of the target domain and allow speakers to understand one domain in terms of another. Orientational metaphors - which involve a spatial relationship of some kind and often fulfil evaluative functions, and ontological metaphors - which provide a fundamental but crude understanding of target concepts and often serve as the bases for structural metaphors (p. 40). Metaphorical mappings are partial, so that they highlight part of the target, while they hide another (p. 90). Furthermore, part of the power of metaphor resides precisely in metaphorical entailment: the set of inferences needed to understand a metaphor, or what Kövecses (2002) defines as the rich knowledge about the source domain that is mapped onto the target domain (p. 104). Importantly, metaphors in public and private discourse have the potential to be repurposed in order to contest dominant representations, in a political strategy that Santa Ana (2002) calls respecifying domains (p. 297).

\section{Metonymy}

Another type of non-literal language included in this study is metonyms. Metonyms involve part-to-whole associations: The word used to name a part of something is used to refer to the whole, or the whole is referred to in terms of something associated with it (Knowles \& Moon, 2006, p. 8). Kövecses (2002) defines metonymy as "a cognitive process in which one conceptual entity, the vehicle, provides mental access to another conceptual entity, the target, within the same domain, or idealized cognitive model" (p. 145). As Knowles and Moon point out, metonyms, like metaphors, are conceptual in nature and have an experiential basis. Lakoff and Johnson ([1980] 2003) argue that metonyms, like metaphors, structure not just language, but also our thoughts and attitudes (p. 37).

There are at least three fundamental differences between metaphors and metonyms. First, there is some observable, very often physical connection between the metonym and its mean- 
ing (Knowles \& Moon, 2006, p. 9). While metaphors highlight similarities between two entities that represent two different domains, metonyms belong to the same domain (p. 53). A metonym helps us to refer to something by mentioning one of its components - or something closely associated to it, while a metaphor helps us to understand or interpret it by comparing it to something else (p. 54).

\section{Referential strategies and social deixis}

A third way to examine how bilingual speakers position themselves in respect to the different groups that constitute a border community such as El Paso, is to look at their conceptualizations of social boundaries as expressed in their use of referential discourse strategies and deictic markers that perform referencing functions. In the past 30 years, several language maintenance models-among them most notably the ethnolinguistic vitality framework, have identified speakers' strong in-group perception as a precondition for minority language viability (Yagmur \& Ehala, 2011).

Referential discourse strategies are resources that speakers/writers draw upon to represent social actors in discourse (Van Leeuwen, 1996, p. 32, in Hart, 2010, p. 56). As such, they aid in the construction of social boundaries because they mark group membership. Hart (2010) argues that in-group referential strategies help to fulfil the human desire for solidarity, rapport, safety or psychological comfort that comes from sharing things with people (p. 60), and that their use is intrinsically ideological, because boundaries between social groups are not natural, but imposed by social actors (p. 61). Some referential discourse strategies relevant to the study of in-group/out-group distinctions in the present study are nationalization - use of nationyms, de-spatialization - use of nationyms, athroponyms, actionyms, metonymic toponyms, and metaphors of spatiality, dissimilation - use of xenonyms, anthoponyms, and metaphors of spatiality, and collectivization - use of pronouns and possessives (Hart, 2010, p. 57). Because of this potential to construct social boundaries, referential strategies are understood by Duszak (2002, p. 5, in Hart, 2010, p. 56), as part of social deixis.

Traditional accounts of deixis (Levinson, 1983), distinguish between personal and spaciotemporal deixis on one hand and social deixis on the other-e.g. honorifics, forms of address. An important claim within the critical discourse analysis framework, however, is that all deictic elements inherently convey social deixis, because their usage relies upon and reproduces knowledge of social identities and relations (Hart, 2010, p. 59). An example of the ideological content of certain deicitic expressions is the changing referent of the pronoun "we" in political discourse, as analyzed in recent sociological studies of nationalism (Petersoo, 2007a, 2007b). Spacio-temporal references are also related to the strategy of proximization, which Hart defines as a kind of conceptualization in which something that is located outside the deictic centre is represented as entering or approaching it with immediate material and ideological consequences (p. 84). In this study, the metaphorical performance of another's voice was considered an expression of social deixis because this is a particular type of performance that achieves a strong perlocutionary effect by indexing a speaker's sociocultural identity through the projection of the imagined qualities of his or her voice and discourse. Metaphorical performance of another's voice is an example of what Oropeza-Escobar (2011) defines as represented discourse: "a means of bringing other discourse, real or imagined, inside the time or space of our own (...) by pretending to reproduce it verbatim" (p. 1).

In the following section, the reader will find the details of a study that illustrates how a group of adult bilinguals articulated their understandings and evaluation of language use and users in their community through metaphorical discourse, referential strategies, and expressions of deixis. 


\section{The participants}

This analysis is part of a larger study on parental attitudes and motivations towards Spanish transmission in several MexAm communities. Five El Paso (EP) families were chosen to participate based on the following criteria: all were two-parent households with at least one child under 18 living at home, and both parents were native speakers of Mexican or MexAm Spanish. All had two children under 18, were middle class and belonged to the same social network. Both parents worked outside the home. Two sets of parents were second-generation El Pasoans. Three were born on the Mexican side of the border, and had spent most of their life commuting between Juárez and EP. These families had relocated to EP less than 12 years prior to the time of data collection. Adults in these three households interacted exclusively or predominately in Spanish at home. One pair of second-generation parents spoke Spanish only when Spanish-dominant speakers were present. The other second-generation couple reported using both languages when addressing each other.

Despite the fact that the 10 children in these households had contact with Spanish-dominant family, neighbors, and friends, and that their parents held positive to very positive attitudes towards Spanish use, a marked shift to English was observed in three first-generation children being raised by first-generation parents. Two children in one second-generation household had only receptive skills in Spanish. In the original study, all families but one obtained very high scores in the areas of opportunity for interaction in Spanish within extended family and community, and parents' use of Spanish. In three of these five families, very low scores were reported for opportunities to develop Spanish literacy. The two families with the highest score for ethnic pride/bilingual identity were also the two families with the highest scores for opportunities for development of literacy in Spanish.

Reported data on opportunities for use were obtained through the use of a 19-item questionnaire intended to explore: children's exposure to Spanish through contact with adults in household, extended family, and community; children's opportunities to use Spanish with peers and adults; family's consumption of Spanish language media; expressed parental support and modelling of ethnic pride and bilingual identity and, finally, opportunities for development of literacy in Spanish - e.g. parent's modelling of reading in Spanish, parent's reading to children in Spanish, availability of Spanish language books in the household, and children's participation in bilingual education.

An analysis of preferred language by type of interaction was performed for the mother and children in each household. Fifteen common household interactions were surveyed. Results show that all mothers used more Spanish than their children, and that they used more Spanish with their youngest child than with their eldest. The present analysis focuses mothers' discourse because results of the original study (Velázquez, 2008), suggest that families which expended greatest effort and resources in fostering oral and written competence in their children where those in which the mother perceived Spanish as an important component of her children's identity, and viewed the language as an instrument to access future economic opportunities.

\section{Method}

Respondents were asked to participate in two in-depth sociolinguistic interviews and were interviewed in Spanish, at home, twice in the space of two weeks, by a female speaker of Mexican Spanish. Discussion of personal topics was facilitated by the fact that the researcher was a second-order acquaintance, and had visited their home and interacted with their family on multiple occasions. Five instruments were used to gather information on perceptions of ethnolinguistic vitality for Spanish, attitudes and motivations towards Spanish use and transmis- 
sion, family practices that could foster or hinder Spanish development, household language use and mother's social network. In the Rosales and Buendía households the father participated in all or part of the recording sessions. These responses were not included in this analysis. Sessions with Ana Buendía - a second-generation speaker, were conducted in Spanish and English, with the researcher following the respondent's choice of language. Data for the present analysis comes from seven hours of recorded interviews with the mothers of these five families. Three hundred and ninety-one pages of transcripts were examined. A total of 544 token-353 types, of non-literal references were identified. Of this total, 250 referred to processes, actors, institutions, and ethnic groups related to Spanish or English use. This smaller group constitutes the corpus for analysis and were categorized as metaphors or metonyms according to their structure. Metaphors were subcategorized as ontological, orientational, or structural. Referential strategies and deictic markers indexing ethnocultural membership were also analyzed. These included nationyms, anthroponyms, actionyms, and xenonyms, as well as first and third person plural pronouns, possessive determiners, object pronouns, first and third-person plural verb endings and third-person singular verb endings when co-appearing with references to a generalized other-e.g. el mexicano trabaja mucho, or the indeterminate pronoun uno - e.g. uno trabaja mucho.

\section{Results}

Two hundred and thirty-four metaphorical references to languages and language users were found in the 10 interviews included in this analysis. No creative metaphors were found. Only one example of mixed metaphor was found: Bilingüe entre lineas. ${ }^{1}$ The most common were ontological metaphors -101 tokens. These are presented in Table 1. As stated before, ontological metaphors help speakers to conceptualize events, abstract ideas, and emotions in terms of concrete entities and natural forces. Ontological metaphors included in this analysis involved conceptualizations of language, culture, and ethnicity as physical objects or natural forces. Instances of personification - e.g. radio de habla hispana, muchas escuelas salieron, were classified as ontological metaphors because they allow the speaker/hearer to understand nonhuman entities in terms of human motivations or activities.

According to the type of metaphorical relationship involved, ontological metaphors were sub-classified into two groups. Most common were entity metaphors - an abstract idea is conceptualized as an object or physical force, as opposed to substance metaphors - an abstract idea is conceptualized as material. The largest group by number of tokens were ontological metaphors in which language and culture - and, in smaller number, other abstract concepts such as work or social protocols, were conceptualized as objects that can be held, manipulated, used as an instrument or abandoned. Perhaps not surprisingly in conversations related to language maintenance and loss, a difference was observed in the conceptualization of Spanish and English. With some exceptions, the verbs most commonly appearing with representations of Spanish as an object were: perder, conservar, dejar, and tener - to lose, conserve, leave or have. Verbs most commonly appearing with representations of English as an object were agarrar and levantarto pick up, to hold or lift up. Bilingualism was primarily conceptualized by these speakers as an instrument: abrir puertas, salir adelante, sacar de problemas - open doors, get ahead, get out of trouble. The use of the verbs agarrar and levantar in the following examples is possibly a calque from the English construction to pick up. More data are needed to corroborate this observation. What is interesting to note however, is that [agarrar + intangible entity] is present in interviews with both first and second-generation speakers, while the only example of [levantar + intangible entity] was found in one interview with Rosy Martínez, a second-generation El Pasoan. 
Table 1. Metaphors (token).

Ontological metaphors (Abstract idea conceptualized as object, physical force, substance or container)

Entity metaphors (abstract idea is conceptualized as object or physical force)

LANGUAGE/CULTURE IS GRASPABLE OBJECT e.g.: va a agarrar muy fácil el inglés; esperando que no lo pierdan (el español)

PERSONIFICATION e.g.: radio de habla hispana; dos idiomas que va a llegá a sacarte de problemas

LANGUAGE USE IS PHYSICAL FORCE e.g.: no impongo mucho el español en mi casa; me la forzaron mucho (a hablar español)

AMOUNT/ ABILITY/SUCCESS IS PHYSICAL STRENGTH/SIZE e.g.: A bigger population of them coming over here; los ejecutivos más grandes (no hablan español)

PSYCHOLOGICAL STRESS IS PHYSICAL PRESSURE e.g.: Ya no te sientes tan presionado (cuando sabes hablar inglés)

Substance metaphors (abstract idea is conceptualized as material)

LANGUAGE/CULTURE IS A SUBSTANCE (amount, purity, admixture) e.g.: puro español; puro inglés; no me revuelvas; que mis hijos se integraran al inglés; que mis hijos se integraran a la cultura americana

COMMUNITY IS PHYSICAL OBJECT e.g.: (substracting contribution made by Mexicans to local economy) sería como quitarle una patita a la mesa

Subtotal

Structural metaphors (One concept or entity is understood in terms of another)

LANGUAGE LEARNING IS WAR/STRUGGLE e.g.: está batallando para escribirlo; batallo mucho más para tratar de entender

LANGUAGE IS A BUILDING/PHYSICAL STRUCTURE e.g.: buenas bases para el español

LANGUAGE IS AWEAPON e.g.: con que se sepan defender; la enfrentaría en inglés

LANGUAGE/CULTURE IS A PLANT e.g.: que no pierdan sus raíces, because of their roots here

LANGUAGE PRACTICE IS DESEASE/DECAY e.g.: ya se me está pegando (mezclar); como si estuvieras degenerando un poco el idioma

METAPHORICAL PERFORMANCE OF ANOTHER'S VOICE e.g.: "ACCENto"; "No hablo inglés"; "Te quiero hasta la vida, hasta la moon"

LANGUAGE IS A BODY e.g.: hablar moch

HUMAN IS ANIMAL e.g.: La burra me contesta en ingles; Chinches Bravas

Subtotal

Orientational metaphors (Abstract idea is conceptualized as a spatial relation)

Metaphors of space

METAPHORICAL REPRESENTATIONS OF SPACE e.g.: en el este (vive) la gente regular, la que trabaja

LANGUAGE/COMMUNICATION/CULTURE IS SPACE e.g.: que no se quedaran en un solo idioma; ella tuvo una transición más rápida, más clara (al inglés)

TIME IS SPACE e.g.: oportunidades en el futuro

ATTENTION IS POINT IN SPACE e.g.: Nonfocaban en losotros

Metaphors of movement or trajectory

LANGUAGE IS A PATH e.g.: a ver cómo les va con el inglés; seguirle enseñando español

MORAL/SOCIAL DAMAGE IS PHYSICAL SEPARATION e.g.: me tira pa' la esquina; las maest ras los hacían pa'un lado

TRUTH/LANGUAGE IS INSIDE e.g.: te salen con que no saben nada de español; en español me sale más suave; a veces sale con su inglés; no te sale el inglés como debería salirte

MORE/BETTER IS UP e.g.: una ciudad de prominencia anglosajona; trabajos de niveles más altos

ECONOMIC/SOCIAL ADVANCEMENT IS MOVEMENT e.g.: si quieres progresar, irte

INTENTION IS MOVEMENT e.g.: ventas hacia la gente de Chihuahua

ECONOMIC ACTIVITY IS MOVEMENT e.g.: (Los mexicanos) Son los que mueven todo

Metaphors of depth

MEANING/FEELING IS PHYSICAL DEPTH e.g.: cuando uno aprende una idioma profunamente

Subtotal

Mixed metaphors (Conceptualization based on two unrelated metaphors) 
[Example 1, Tere Rosales, session 1]

TR: [En la escuela] Va a agarrar muy fácil en inglés. [In school] He is going to pick up English very easily.

[Example 2, Rosy Martínez, session 2]

RM: [Talking about the languages her daughter speaks most often when giving her advice] Yo digo que las dos. Más bien inglés, pero, a veces las ... lo mizcla para agarrar más sintido. I think both. More English, but, sometimes, she mixes them to pick up/convey more feeling/meaning.

[Example 3, Rosy Martínez, session 1]

RM: Entonces, es cuando comprendí, que, cuando uno aprende una idioma profunamente (...) muy bien (...) es más fáci levantá[ø] otra, otra ... (...) otra idioma. That's when I understood that when you learn a language deeply $(\ldots)$ very well $(\ldots)$ it's easier to pick up another, another language.

The second group of ontological metaphors includes 35 tokens in which language, culture, and ethnicity are conceptualized as a substance-related to amount, purity, and admixture. Twenty-three per cent of these were tokens of the adverbial construction (hablar) puro español or (hablar) puro inglés, which is not a metaphor of purity, but of amount. ${ }^{2}$ With a very small number of tokens each, other ontological metaphors found in the corpus were: LANGUAGE USE IS PHYSICAL FORCE, AMOUNT/ABILITY/SUCCESS IS PHYSICAL STRENGTH/ SIZE, PSYCHOLOGICAL STRESS IS PHYSICAL PRESSURE, and COMMUNITY IS PHYSICAL OBJECT.

Forty-three structural metaphors were found. These involved mapping the structure of a concrete, tangible source domain onto the abstract and intangible target domains of language, culture, and community. By type of metaphorical relationship involved, eight types of structural metaphors were found. The largest in number were conceptualizations of language learning as war or physical struggle-12 tokens. Examples of this subgroup are: está batallando para escribirlo, estás contra la corriente (si no quieres aprender inglés) - sometimes a word gets stuck, she's struggling to write it, you are going against the current (if you do not want to learn English). The second was LANGUAGE IS A BUILDING/PHYSICAL STRUCTURE-Deben tener los dos idiomas bien fuertes; buenas bases para el español. Because of space constraints, not all structural metaphors found will be discussed here. Three subgroups with a low number of tokens are discussed below because of their strong evaluation component. The first is the conceptualization LANGUAGE IS A WEAPON - con que se sepan defender, la enfrentaría en inglés. The second involves conceptualization of code-switching as disease or decay-Only five tokens. Some examples are: ya se me está pegando, como si estuvieras degenerando un poco el idioma (el español de El Paso) está tan echado a perder, I use the wrong kind of (...) slang words. ${ }^{3}$ These negative evaluations of code-switching can be contrasted with example 2, in which Rosy Martínez - a second-generation speaker, frames this practice as a way to convey greater depth of feeling or meaning.

Differences in evaluation were also observed in the three examples of metaphorical performance of another's voice found in the corpus. Examples 4 and 5 are instances of represented discourse. In example 4, which conveys positive evaluation, Rosy Martínez metaphorically reproduces her daughter's discourse when communicating affection:

[Example 4, Rosy Martínez, session 2]

RM: Me dice "mamá te quiero, te quiero, hasta la vida, hasta la moon, I love you." She tells me "mom I love you, I love you, to (the end off) life, to the moon, I love you." 
In example 5, Lala Macedo, a first-generation speaker, metaphorically reproduces the discourse of an imaginary Mexican client who comes into her place of business and does not know how to speak English. She conveys negative evaluation by identifying the metaphorical speaker's place of origin in Chinches Bravas - Literally: Ferocious bedbugs, by using the nonstandard form pos, and by changing her tone:

[Example 5, Lala Macedo, session 1]

I: Y cuando estás en el trabajo y recibes un cliente, ¿cómo sabes si le hablas en español o en inglés?

LM: Es que inicias la conversación en inglés y ya él te dice cómo quiere que le hables (...) la conversación se inicia siempre en inglés, siempre tiene que ser en inglés ... (...) A menos que ya lo conozcas, ¿ve[ø]dá? Que sabes que ... que viene de allá de Chinches Bravas, pero ... pero no ...

I: [¿Qué es Chinches Bravas?

LM: Chihuahua. [Laughs] Pero nooo, tienes que iniciar la conversación en inglés, a fuerzas... ya él te dice "no, pos no hablo españo ... no hablo inglés," entonces ya ...

I: And when you're at work and a client comes in, how do you know if you should speak Spanish or English to him/her?

LM: You start the conversation in English and he tells you how he wants you to address him (...) the conversation is always started in English, it has to be in English always ... (...) Unless you know him, right? That you know that ... that he comes from over there, from Chinches Bravas, but ... but no ...

I: [What is Chinches Bravas?

LM: Chihuahua. [Laughs] But nooo, you have to start the conversation in English, you have to... and then if he tells you "no, well I don't speak Spa ... I don't speak English", then you ...

In example 6, Macedo coveys a negative evaluation of speakers of MexAm English and Spanish by raising her tone and intentionally mispronouncing the Spanish word acento.

[Example 6, Lala Macedo, session 1]

LM: [Speaking about why she thinks only standard English should be taught in El Paso schools] Porqueeee ... ya te di mi punto de vista, yo pienso que deben aprender el inglés. Bien el inglés, no mocho, ni con aCCENto ...

I: [¿Qué tantas personas en El Paso hablan español mocho? ${ }^{4}$

LM: Las maestras de mis niños. ¿Que las que yo conozca? La mayoría de las maestras de mis hijos ... las bilingües ... (...) No les entiendo su español, hablan un ingl ... un español inven- TAdo, no sé de dónde lo sacaron.

LM: [Speaking about why she thinks only standard English should be taught in El Paso schools] Becaaaaause... I already shared my opinion with you, I think they should learn English. Learn it well, not mocho, or with an ACCent.

I: [How many people speak mocho Spanish in El Paso?

LM: My children's teachers. That I know of? Most of my children's teachers ... the bilinguals ... (...) I don't understand their Spanish, they speak an Engl ... an invenTEd Spanish, I don't know where they got it from.

Several examples presented in these pages highlight the importance of standard ideologies of language for three of the five speakers included in this analysis. Examples 5 and 6 in particular, evidence a hierarchy occupied by monolingual or unaccented English at the top, monolingual or unaccented Spanish in second position, and contact varieties of Spanish and English occupying the lowest rung.

Eighty-nine orientational metaphors were found in the corpus. These involved conceptualization of language and culture by means of a spatial relationship. Orientational metaphors were further classified into metaphors of space, metaphors of movement or trajectory, and metaphors of depth. The most common orientational metaphors were metaphorical representations of ar- 
Table 2. Metonyms (token).

\section{Metonyms \\ Part for whole metonyms}

PART STANDS FOR THE WHOLE

El pelo no se nos puede poner güero (Our hair can't turn blond)

El oído de las personas se nos va a acostumbrar (People's ear is going to get used to...)

\section{Container metonyms}

CONTAINER STANDS FOR CONTAINED

Muchas escuelas salieron (a protestar en favor de los inmigrantes) Many schools wet out (to protest in favor of immigrants)

\section{Category metonyms}

PROPERTY OR FEATURE STANDS FOR CATEGORY

There's a lot of Spanish-speaking

For the Spanish-speaking

Gente de color (People of color)

Negros (Blacks)

Morenos (Dark-skinned)

CATEGORY STANDS FOR PROPERTY THAT DEFINES IT

Lo aprendió medio pochito (She learned it a little poshito)

no me gusta que hablen espanglish, pochito (I don't like it when they speak Spanglish, poshito)

\section{Action metonyms}

RESULT STANDS FOR ACTION

No va a ir a la universidad en español (She's not going to college in Spanish)

AGENT STANDS FOR ACTION

Los primeros maestros somos nosotros los papases (We parents are the first teachers)

Como si fueras a ser traductor de la ONU (As if you were going to be a UN translator)

OBJECT STANDS FOR ACTION

(no habla inglés) ni aunque le pagues (He won't speak English) even if you pay him

\section{Other}

POPULAR/HISTORICAL CHARACTER STANDS FOR MORAL FLAW

(Contar) chistes de Pepito ${ }^{10}$ (To tell Pepito jokes)

Somos malinchistas (We are malinchistas)

Total 16

eas within and around the city of El Paso, and LANGUAGE/COMMUNICATION/CULTURE IS SPACE, followed by LANGUAGE IS A PATH.

\section{Metonym}

Only 16 metonyms related to language use and ethnocultural groups in El Paso were found. These are presented in Table 2. Although few in number, several are worth mentioning here because they relate to respondents' perceptions about cultural and linguistic assimilation. Examples 7 and 8 were taken from the first interview conducted with Carmen Mena, ${ }^{5}$ a first-generation speaker who believed that Spanish use and bilingualism in general were positive, but believed that Spanish should not be in taught school because the local variety of Spanish -i.e. MexAm Spanish, was not an educated variety. In example 7, Mena establishes a metonymic relationship between becoming blonde and assimilating into mainstream culture. An important difference in framing is to be noted here between being blonde, and having one's head turn blonde-el pelo no se nos pueder poner güero. The former can be the result of genetics or the aid of the cosmetics industry; the later is framed as an impossibility that is subject to external forces. It is in this entailed loss of control that Mena constructs her negative evaluation about the uncritical adoption of external-i.e. unauthentic cultural models: 


\section{[Example 7, CARMEN MENA, session 1]}

CM: Porque si[ø]stás en Estados Unidos y ése es el idioma, pus habla es ... hablas inglés también. Yo pienso que deben tener los dos idiomas fuertes. Bien hechos, bien estudiados, bien hablados. Y, y de[ø]sa manera te sientes menos mal de hablar español, pero tampoco te menosprecies el español porque te quieras que tus hijos hablen nada más inglés (...) Ó yeme, pues sí tenemos ese origen hispano, el pelo no se nos puede poner güero ...

Because if you're in the United States and that is the language, well speak ... speaker English too. I think that you have to have both languages to be strong. Well formed, well studied, well spoken. And, and that way you feel less bad about speaking Spanish, but don't underestimate Spanish and want your children to speak only English (...) Listen, if we have that Hispanic origin, our hair can't turn blonde.

In example 8, Mena expresses her concern for the quality of both Spanish and English that her younger daughter was learning in school, and questions the qualifications of the teachera speaker of MexAm Spanish. She also explains her perception of code-switching as a practice associated with uneducated people. In both examples, Mena uses the adjective pocho-which, as a speaker of Chihuahua Spanish, she pronounces as [pólo]. The adjective pocho is most commonly a derogatory label used in reference to a MexAm perceived to have embraced Anglo cultural norms and reneged of his or her cultural heritage. ${ }^{6}$ It is relevant to note that in this example Mena uses the diminutive-ito as a hedging or mitigating device, perhaps because she is referring to her own daughter's speech:

[Example 8, CARMEN MENA, session 1]

CM: [Referring to her older daughter's reading and writing skills in both languages when her family first arrived in El Paso] No sabía escribir el inglés. El español así, mira [moves right hand signaling "so so"] [Laughs] medio pocho. No realmente el español que estaba acostumbrada yo a escuchar de cuando iba mi hija a la escuela allá en Juárez. Entonces lo aprendió medio pochito, porque un día llegó de la escuela diciéndome que blusa se decía en inglés, blus (...) Entonces, ella no me creía a mí que era de otra manera, porque la maestra le había dicho así, entonces la maestra yo digo, bueno, no tenía muy buena preparacio 'n ella para, para el inglés probablemente ¿verdá[Ø]? (...) a mí no me gusta que mezclen... no me gusta que hablen el espanglish, pochito.

I: Para ti, una persona que mezclaaa, ¿qué, qué representa?

CM: Ah ... poquito de falta de educación (...) Como que les faltó un poquito más de escuela, de ... de saber cómo pronunciar bien, o como decir bien las palabras

CM: She didn't know how to write in English. In Spanish like this, look [moves right hand signaling "so so"] [Laughs] a little pocho. Not really like the kind of Spanish I was used to hearing when she went to school over there in Juárez. So she learned it a little pochito, because she came home from school one day and told me that blusa in English was blus (...) so she didn't believe me that it was otherwise, because her teacher had told her, so the teacher, I think, well, wasn't very well prepared to teach English, right? (...) I don't like it when they mix ... I don't like them to speak Spanglish, pochito

I: For you, a person that mixes, what does he/she represent?

CM: Ah ... lack of education, a little (...) like they're missing a little bit of schooling, of ... of knowing how to pronounce correctly, how to say the words correctly.

In example 9, Ana Buendía, a second-generation speaker whose children had only receptive skills in Spanish, is explaining her family's decision to enroll her youngest son in a monolingual English preschool class after the school's dual language program was closed for what parents were told was a lack of enrollment. Both parents saw this a lost opportunity for their child. According to her own account, the school offered one preschool class where both languages were used, but enrollment was targeted to children from low-income families, many of them recent immigrants from Mexico. In example 9, Buendía uses the nominalization the Spanish-speakinghighlighting a feature or characteristic of the group, to avoid using the adjective Mexican. 
[Example 9, ANA BUENDÍA, session 1]

AB: So, they, they took the, the class out, and uh, he's just uh, in the monolingual class.

I: Why do you think they didn't have enough children? It's hard to think that there were, that there wouldn't be ...

AB: [Laughs]

I: Enough children in El Paso.

$\mathrm{AB}$ : They do have a class where it's all like the Spanish-speaking, children ...

I: $[\mathrm{Mhm}$.

AB: They do have a class like that, but, like, where they show them both languages ...

I: $[\mathrm{Mhm}$.

AB: They, they ... I don't know, I don't know why they took it out. (...)

Husband: [Asking his wife] They base themselves a lot on, on income, también, ¿no?

AB: Ajá. Like M [Younger son], he couldn't... I couldn't register him for Pre-K ...

I: [Mhm.

AB: He either had to be, Spanish-speaking, or we had to qualify because of our income.

In examples 10 and 11 Buendía refers to her colleague and teaching partner, who was born in Mexico, and to the students in her class, whose families are Mexican or of Mexican descent. In both examples she uses the construction She/they speak(s) Spanish, to avoid using the adjective Mexican:

[Example 10, ANA BUENDÍA, session 1]

I: Ehm, en un día normal, in a normal day, you would have to use Spanish, you were where, with whom?

AB: Well, with the tea ... with my, partner. She's one hundred per cent, she speaks Spanish, so I would have to speak Spanish with her ...

[Example 11, ANA BUENDÍA, session 1]

AB: [Talking about the students in her classroom] Half of them are, uh, speak Spanish.

\section{Deixis}

The third part of this analysis involves examination of the referential strategies and expressions of deixis that helped El Paso respondents to position themselves with respect to the different ethnocultural groups in their city. These are presented in Table 3. A total of 241 references to members of different ethnic or cultural groups in the city were found. First and third-person plural expressions of deixis were organized according to their referent. Six groups were identified in the corpus. Most first-person plural references-e.g. us, we, our, corresponded to hispanos and mexicanos and most third-person plural references-e.g. they, them, their, corresponded to mexicanos and americanos/gringos/anglos. The construction Gente de El

Table 3. Referential strategies and expressions of deixis (token).

\begin{tabular}{lrr}
\hline Expressions of deixis & Us & Them \\
\hline Hispanos & 27 & 31 \\
Mexicanos & 26 & 58 \\
Gente de El Paso & 5 & 22 \\
Chicanos/MexAm/speakers of MexAm Spanish & 0 & 8 \\
Gringos/Americanos/Anglos & 0 & 52 \\
Other & 0 & 12 \\
Total & 58 & 183 \\
\hline
\end{tabular}


Paso - people from/in El Paso, was most commonly used in reference to a generalized other. With few exceptions, most references in the category of other indexed soldiers, African Americans, ${ }^{7}$ and German nationals living in or around the local military base. All respondents selfidentified as hispana. No examples of first-person singular reference as mexicana, chicana, mexicanoamericana, americana, or latina were found. All references that indexed Mexican nationality or origin were qualified-e.g. La gente que venimos como de allá de Juárez-[We] people who come like from over there from Juárez; los mexicanos que vivimos acá- [we] Mexicans who live over here. Although no respondent self-identified as Mexicana, indexing of group membership as mexicanos through use of first-person plural forms was second in number to hispana/hispano and related forms. This shifting "we" (Petersoo, 2007a) in relation to the identifier Mexican is illustrated on examples 12 and 13, in which Lala Macedo, a first-generation speaker, hedges a negative evaluation of Mexicans according to their position as $u s$ or them. In doing this, she reproduces a stereotype frequently used in local discourses opposing bilingual education:

[Example 12, LALA MACEDO, session 1]

LM: [Los mexicanos] Vienen sin aprender, jamás aprenden inglés bien. [Mexicans] come without learning, they never learn English correctly. [Emphasis is mine].

[Example 13, LALA MACEDO, session 1]

LM: [Referring to her own children] Todavía no saben hablar inglés. [Referring to her own children] They don't know how to speak English yet.

On example 14, Carmen Mena, a first-generation speaker, shifts deictic centre within the same sentence-from first to third-person plural, distancing herself from her own negative evaluation of hispanos and their English language skills:

[Example 14, CARMEN MENA, session 1]

CM: Algunos de los hispanos questamos aquí, esteee, hablan algunas palabras queee, que si no hablas español no vas a saber qué están diciendo. Some of (us) Hispanos that are here, I mean, (they) use some words thaaat, if you don't speak Spanish, you're not going to know what they're saying.

A difference was found in the patterns of ethnic identification of the two second-generation respondents. For Ana Buendía, who had a positive perception of Spanish in the community but did not believe herself to be a competent speaker, and was not transmitting the language to her children, Mexicans were them. For Rosy Martínez, who also had a positive perception of Spanish, but, in contrast, had expended considerable time and effort helping her children become bilingual, Mexicans were us:

[Example 15, ANA BUENDÍA, session 1]

$\mathrm{AB}$ : We have a bigger population of them coming over here.

[Example 16, ROSY MARTÍNEZ, session 1]

RM: Uno de mexicano sigue trabajando $\mathrm{pa}[\varnothing]$ poder tené[Ø] algo en la vida. As a Mexican you keep working so you can have something in life.

\section{Referential strategies}

Because of the rich verbal morphology of Spanish, all conjugated verb forms performed the function of collectivization. This function was also performed by pronouns and possessives. The second most common referential strategy found in the corpus was dissimilation, usually 
involving an anthroponym that functioned as an ethnic identifier ${ }^{8}$ - e.g. hispano, gringo, anglo, árabe. Other examples of dissimilation include actionyms - e.g. la gente que venimos como de allá de Juárez; metonyms - la gente de color, and anthroponyms indexing occupation-e.g. soldados. Consistent with the fact that El Paso is a border community, the word mexicano-Mexican, and all related forms, performed two different referential functions according to context: $n a-$ tionalization, when it was used in reference to a citizen of the nation of Mexico, and dissimilation, when used in reference to a person of Mexican descent was born or resided in the USA. In several examples, Mexicans were further classified by social class - e.g. mexicanos pobres, poor Mexicans; mexicanos de dinero, Mexicans with money, la gente como uno, people like us, and by area within the city -i.e. middle class to the east, lower class to the south, and upper class to the west. The final two examples illustrate the different ways in which speakers either reproduced or contested negative ideologies about Mexicans. In example 17, Lala Macedo, a firstgeneration immigrant to El Paso, reproduces the stereotype of Mexican immigrants as people who take unfair advantage of public resources and refuse to learn English. In example 18 Rosy Martínez, a second-generation El Pasoan, subverts a negative stereotype that frames Mexicans as lazy or lacking in ambition:

[Example 17, LALA MACEDO, session 1]

LM: Mira, te voy a aplicar un ... una ... una amiga que yo tengo que es de Irán, y ella ... ella tiene razón, dice "mira, yo cuando me vine con mis hijas, mis hijas tuvieron que aprender inglés para ir a la escuela, jámás les dijeron "okey, vente y yo te voy a dar la clase en ... en iraní" (...) Entonces ella, ella piensa que... yo pienso igual que ella, que no es justo que a los ... a la mejor porque es mayoría ... pero no es justo que porque vienen los mexicanos sin aprender inglés les van a dar español en las escuelas, y pueden durar hasta la high school y jamás aprenden el espa ... el inglés bien, yo pienso que está mal.

LM: Look, I'm going to apply a ... a ... I have a friend from Iran and she... she's right, she says "look, when I came with my daughters, my daughters had to learn English to go to school and they never told them "ok, come and I'll teach you in Iranian" (...) So she, she thinks that ... and I think like her, that it's not fair that because Mexicans come without learning English they're going to teach them Spanish in school, and they can go on to high school and they never learn Sp ... English well, I think that is wrong.

[Example 18, ROSY MARTINEZ, session 1]

I: ¿Qué tan importantes son los mexicanos para la economía de El Paso?

RM: Muuy importante. Son los que mueven todo. Son los que mueven todo. Hay un dicho que dice que los gringos son un poco más flojos que los mexicanos. (...) Los mexicanos siempre, maduran más, y quieren más en la vida porque tienen sueños (...) Y los gringos... tienen sueños porque sus papases o sus agüelos dejaron diñero (...) Y por eso siguen con negocio, pero uno de mexicano, sigue, trabajando duro para podé[Ø] tené[ø] algo en la vida, para su, para su familia, pa sus hijos, pa[Ø] dejáles algo.

I: How important are Mexicans for El Paso's economy?

RM: Veery important. They move everything. They move everything. There is a saying that says that Gringos are a little lazier than Mexicans. (...) Mexicans always, mature more, and want more in life because they have dreams. (...) And Gringos ... they have dreams because their parents or their grandparents left money $(. .$.$) and that's why they go on with a business, but$ as a Mexican, you keep working hard to have something in life, for, for your family, for your children, to leave them something.

\section{Conclusion}

One of the main arguments of this paper has been that any model that attempts to explain patterns of language maintenance and loss must account for speaker conceptualizations about 
language and language users. One way to examine these conceptualizations is to look at metaphors and metonyms. Only 16 metonyms related to language use and ethnocultural groups were found. Two hundred and thirty-four metaphorical references to languages and language users were analyzed. The most common type found was ontological metaphors, which involved conceptualizations of language, culture, and ethnicity as physical objects or natural forces. Within this category, the largest number were conceptualizations of language and culture as objects that can be held, manipulated, used as instruments or abandoned. A difference was observed in the conceptualization of Spanish and English. Verbs most commonly appearing with representations of Spanish as an object were to lose, conserve, leave, or have, while verbs most commonly appearing with representations of English as an object were to pick up, to hold or lift up. Bilingualism was primarily conceptualized by these five speakers as an instrument. Second in number were ontological metaphors in which language and culture were conceptualized as a substance.

Forty-three structural metaphors were found. These involved mapping the structure of a concrete, tangible source domain onto the abstract and intangible target domains of language, culture, and community. The most common included conceptualizations of language learning as war or physical struggle. Two metaphorical representations with a very low number of tokens were discussed here because of their strong evaluation component. These were conceptualizations of code-switching as disease or decay, and metaphorical representation of another's voice. Eighty-nine orientational metaphors were found in the corpus. Greatest in number were metaphorical representations of space, conceptualizations of language and communication as space, and conceptualizations of language as a path.

A second argument made throughout this paper was that individual speaker perceptions about the benefits and drawbacks of language maintenance and loss are couched within the larger landscape of community and national discourses about language use, Latinos, and national identity. One way to examine how speakers position themselves within this landscape, it was argued, was to examine their conceptualizations of social boundaries as expressed in their use of referential discourse strategies and deictic elements. Perhaps one of the strongest contributions of this paper has been to show how the five speakers in this border community made use of referential strategies and deictic markers to construct a dichotomy that was both socially relevant and ideologically powerful. A total of 241 references to members of different ethnic or cultural groups in the city were found. All respondents self-identified as hispana. No examples of first-person reference as mexicana, chicana, mexicanoamericana, americana, or latina were found in the 391 pages of transcripts analyzed for this study. At the same time, although no respondent self-identified as mexicana or Mexican, indexing of group membership as mexicanos through use of first-person plural forms was second in number to hispana/hispano and related forms. Further evidence of the fluid and multilayered nature of identity formations in this border community was found in examples were speakers hedged evaluations of Mexicans according to their position as us or them. In another example discussed in the preceding pages, the speaker shifts deictic centre within the same sentence with the effect of distancing herself from her own negative evaluation. Two metonyms discussed here illustrate the construction of social distinction through reference avoidance. These were the metonyms there's a lot of Spanish-speaking, and for the Spanish-speaking, with which Ana Buendía, a second-generation El Pasoan, referenced the category of Mexican through mention of language use.

The third and final argument made in this paper was that examination of metaphorical references, metonyms, referential strategies, and expressions of deixis related to language use and language users is one way to understand if and how individual discourse maps onto larger language ideologies. Because of its history and geographical location, speakers in El 
Paso engage in a constant exercise of definition and re-definition of their identity in opposition to the imagined other. As illustrated by the examples presented in these pages, these speakers constructed and evaluated identity formations in ways that are considerably more fine-grained and multilayered than broad Latino/non-Latino and bilingual/monolingual dichotomies commonly present in national discourse. Some of these layers include, for example, generation of arrival, place of birth, migratory status, ethnic identification, varieties of Spanish and English spoken, context of interaction, socioeconomic class, perceived degree of cultural assimilation, and geographical location within the city. Examples of both internalization and contestation of larger ideologies of language panic were found and presented here.

This analysis has been an effort to understand how speakers reproduce or contest larger ideologies about language use. It has been argued here that speakers' beliefs about language affect their language use, and ultimately, their perceptions of the cost-benefit of intergenerational transmission of their family language. The analysis presented in the preceding pages outlines and example of language as social practice, because it illustrates how these El Paso speakers used language to enact social boundaries and social identities. Future studies must include larger corpora, data from speakers of different gender, age, and socioeconomic strata, as well as comparison of metaphorical representations of language and language users by bilingual speakers in other communities in the USA.

\section{About the author}

Isabel Velázquez, PhD, University of Illinois at Urbana-Champaign, is assistant professor in the Department of Modern Languages and Literatures, University of Nebraska-Lincoln. Her areas of research include sociolinguistic variation, Hispanic linguistics, bilingualism and language acquisition, heritage speaker pedagogy, language contact on the US-Mexico border, and the role of language in identity formations of US Latina/os. Her current research focuses on linguistic maintenance and loss among Latino families in the Midwest.

\section{Notes}

1. Bilingüe entre líneas-Bilingual between the lines, is a composite of the idiomatic expressions "entre comillas" - between quotation marks, and "(leer) entre líneas" - (reading) between the lines. Both involve conventional metaphors, but precisely because they are a part of everyday language, their metaphoric potential is weak to non-existent.

2. In Spanish, the word puro has an adjectival value when placed after the noun-e.g. chocolate puro (pure chocolate), and an adverbial value when it precedes the noun - puro chocolate (only chocolate).

3. It's sticking to me, as if you were degenerating the language a little [El Paso Spanish] is so spoiled.

4. The expression "hablar mocho" which was found twice in the corpus, and is somewhat common in El Paso to refer to MexAm Spanish. It is most likely a metaphorical extension of the verb mochar - in Mexican Spanish: to amputate or chop off. This use involves the conceptualization of language as a living organism, such as a tree or a body. The online version of El Diccionario del español en México defines the adjective mocho as: "Missing a part, generally because it was broken; missing a tip or an edge (...) In reference to people, missing an arm or a leg or a portion of them; missing a limb" (El Colegio de México, n.d.).

5. All names are pseudonyms.

6. The online version of Guido Gómez de Silva's Diccionario breve de mexicanismos defines pocho as: "A Mexican that has adopted American manners and speech (...) (generally because he/she lives near the Mexico-United States border, on either side)" (Gómez de Silva, 2012).

7. The three references to African Americans found in the corpus are metonyms: negros, gente de color, and morenos.

8. The identifiers mexa, and fronchi were not included in analysis because they were not used by any of the respondents, but will be discussed here because of their relevance to local identity formations. At the time of data collection, mexa was a term used by middle-class first-generation immigrants from Juárez as a semantic counterpart to pocho: a quintessentially Mexican individual who refuses to acculturate 
to Anglo norms. In the following example, taken from the transcript of the first interview with Tere Rosales, the term is used by her husband:

I: And in the Bassett [Mall] area, who lives there?

TR: There it can be more of an American type area. [ ... ]

I: Just arrived, or a long time there?

Husband: No, they've been there a long time. Around here? Only Americans. Over there where my jefa and my B live [Referring to his mother and grandmother], only Mexas!

A related term used in the 1990s, but no longer popular at the time of the interviews, was fronchi, used in reference to a Mexican national who lived on the Ciudad Juárez side of the border but commuted to El Paso to work, study or shop. The term is a clipping of Frontera Chihuahua, which during the 1990s was stamped on the license plates issued by the Chihuahua state government to owners of used cars that had been imported from the USA to Mexico for restricted use in the 30-kilometer border zone (Hill, 2009).

9. Compare three metaphors included in this table-LANGUAGE IS A PATH, TRUTH/LANGUAGE IS INSIDE, and LANGUAGE/CULTURE IS A SUBSTANCE, with two metaphorical representations of language and education discussed in chapter 6 of Santa Ana (2002): EDUCATION AS A PATH - and Spanish use as a barrier on this path (p. 207), and LANGUAGE AS WATER (p. 201). Indeed, it could be argued that TRUTH/LANGUAGE IS INSIDE, and LANGUAGE/CULTURE IS A SUBSTANCE are instances of the LANGUAGE AS WATER metaphor, which Santa Ana understands as a conceptualization of language as fluid, dynamic medium that can be suffused, absorbed, dispensed, and "poured out" onto an external space (p. 202).

10. In Mexican popular culture, chistes de Pepito are lewd jokes in which the character of Pepito, a precocious child, accidentally sets off the action, usually hinging on ambiguity in meaning. The adjective malinchista, from the historical Malinalli, Malintzin, or Malinche, Hernán Cortés' interpreter and concubine, is recorded in the online version of Guido Gómez de Silva's Diccionario Breve de Mexicanismos as: "Someone who suffers the complex of loving that which is foreign and looking down on that which belongs to oneself."

\section{References}

Achugar, M. (2008). Counter-hegemonic language practices and ideologies: Creating a new space and value for Spanish in Southwest Texas. Spanish in Context, 5(1), 1-19.

Del Valle, J. (2000). Monoglossic policies for a heteroglossic culture: Misinterpreted multilingualism in modern Galicia. Language \& Communication, 20, 105-132.

Del Valle, J. (2006). U.S. Latinos, la hispanofonía, and the language ideologies of high modernity. In C. M. Molinero \& M. Stewart, eds., Globalization, language and the Spanish-speaking world (pp. 2746). London: Palgrave Macmillan.

El Colegio de México. (n.d.). El Diccionario del español en México. Accessed May 7, 2012, from http:// dem.colmex.mx/

Gómez de Silva, G. (2001). Diccionario breve de mexicanismos. México: Fondo de Cultura Económica.

Hart, C. (2010). Critical discourse analysis and cognitive science: New perspectives on immigration discourse. Basingstoke: Palgrave MacMillan.

Hidalgo, M. (1995). Language and ethnicity in the "taboo" region: The U.S.-Mexico border. International Journal of the Sociology of Language, 114(4), 29-42.

Hill, S. (2009). El dompe, los yonkes, and las segundas. Consumption's other side in El Paso-Ciudad Juárez. In A. McCrossen, ed., Land of necessity: Consumer culture in the United States-Mexico borderlands (pp. 298-324). Durham, NC: Duke University Press.

Knowles, M., \& Moon, R. (2006). Introducing metaphor. London: Routledge.

Kövecses, Z. (2002). Metaphor: A practical introduction. Oxford: Oxford University Press.

Kristiansen, T., Garret, P., \& Coupland, N. (2005). Introducing subjectivities in language variation and change. Acta Linguistica Hafniensia, 37(1), 9-35. 
Kroskrity, P. V. (2000). Regimenting languages. In P. V. Kroskrity, ed., Regimes of language. Ideologies, polities, and entities (pp. 1-34). Santa Fe, NM: School of American Research Press.

Lakoff, G., \& Johnson, M. ([1980] 2003). Metaphors we live by (2nd ed.). Chicago, IL: University of Chicago Press.

Levinson, S. C. (1983). Pragmatics. New York: Cambridge University Press.

Martínez, G. A. (2006). Mexican Americans and language. jDel dicho al hecho!. Tucson: University of Arizona Press.

Olneck, M. R. (2006). Assimilation and American national identity. In R. Ueda, ed., A companion to American immigration (pp. 202-224). Malden, MA: Blackwell.

Oropeza-Escobar, M. (2011). Represented discourse, resonance and stance in joking interaction in Mexican Spanish. Amsterdam: John Benjamins.

Petersoo, P. (2007a). Reconsidering otherness: Constructing Estonian identity. Nations and Nationalism, 13(1), 117-133.

Petersoo, P. (2007b). What does "we" mean? National deixis in the media. Journal of Language and Politics, 6(3), 419-436.

Santa Ana, O. (2002). Brown tide rising: Metaphors of Latinos in contemporary American public discourse. Austin: University of Texas Press.

Teschner, R. (1995). Beachheads, islands, and conduits: Spanish monolingualism in El Paso, Texas. International Journal of the Sociology of Language, 114, 93-105.

Velázquez, I. (2008). Intergenerational Spanish language transmission: Attitudes, motivations and linguistic practices in two Mexican American communities. PhD dissertation, University of Illinois at Urbana-Champaign.

Velázquez, I. (2009). Intergenerational Spanish transmission in El Paso, Texas: Parental perceptions of cost/benefit. Spanish in Context, 6(1), 69-84.

Yagmur, K., \& Ehala, M. (2011). Tradition and innovation in the ethnolinguistic vitality theory. Multilingual and Multicultural Development, 32(2), 101-109. 